\title{
The Reasonable Justice: An Empirical Analysis of Frank Iacobucci's Career on the Supreme Court of Canada
}

\author{
Benjamin Alarie and Andrew Green
}

\author{
Version Publisher's version
}

Citation Benjamin Alarie \& Andrew Green, "The Reasonable Justice: An

(published version) Empirical Analysis of Frank Iacobucci's Career on the Supreme Court of Canada" (2007) 57:2 University of Toronto Law Journal 195-226.

Publisher's Statement Reproduced with permission of the University of Toronto Faculty of Law Journal.

How to cite TSpace items

Always cite the published version, so the author(s) will receive recognition through services that track citation counts, e.g. Scopus. If you need to cite the page number of the author manuscript from TSpace because you cannot access the published version, then cite the TSpace version in addition to the published version using the permanent URI (handle) found on the record page.

This article was made openly accessible by $U$ of $T$ Faculty. Please tell us how this access benefits you. Your story matters. 
Benjamin R.D. Alarie \& Andrew Green*

THE REASONABLE JUSTICE: AN EMPIRICAL ANALYSIS OF FRANK
IACOBUCCI'S CAREER ON THE SUPREME COURT OF CANADA

I Introduction

There are two widely shared views of Frank Iacobucci as a justice of the Supreme Court of Canada. The first is that he was a liberally inclined justice, particularly in the area of criminal law. ${ }^{1}$ That he has conventionally been regarded as a liberal despite being appointed in 1991 by the Progressive Conservative prime minister Brian Mulroney raises a number of questions. Is this conventional view of Justice Iacobucci actually correct? That is, is it borne out by his voting record over his more than thirteen years on the Court? If so, does this 'left of centre' claim hold fast beyond criminal law and extend to other areas of law? If it were the case that Justice Iacobucci was consistently left of centre, then it could be claimed either that Mulroney misapprehended his chosen nominee's political leanings or that he made his choice on the basis of factors - such as merit - unrelated to Justice Iacobucci's political inclinations. Another possibility, perhaps less likely, is that Mulroney actually preferred to appoint someone who would be somewhat left of centre. Yet another possibility is that Mulroney accurately assessed Justice Iacobucci's political leanings as a conservative at the time of his appointment, but that Justice Iacobucci shifted to the left over the course of his tenure on the Court. $A$ priori, these explanations are all more or less plausible.

* Faculty of Law, University of Toronto. The authors wish to thank Amy Murakami, Timothy Ho, Justin Jacobs, and Michael Decicco for invaluable research assistance, and participants at the Frank Iacobucci Symposium, the 2006 Canadian Law and Economics Association conference, and the Wilfrid Laurier University economics workshop for helpful comments.

1 See, e.g., Patrick Monahan, 'Supreme Control: Is It Jean Chrétien's Court?' Globe and Mail (27 June 2003) A15: 'Mr. Justice Frank Iacobucci, is often seen as being in the "liberal wing" of the Supreme Court, with a great tendency to favour claimants seeking protection under the Charter of Rights and Freedoms'; and Kirk Makin, 'An Emotional Champion for the Accused: Supreme Court Justice Frank Iacobucci' Globe and Mail (7 April 2000) A7 [Makin, 'Emotional'], quoting Jacob Ziegel: 'He is somewhat left of centre in the criminal-law area and has shown a strong partiality for egalitarian principles. He has a very strong liberal bias.' Similarly, see John Jaffey, 'Iacobucci Lectures at Labour Law Conference in London' Lawyers Weekly (5 November 2004) 3: '[F]ormer Justice Iacobucci's many important labour law decisions are themselves a legacy to Canadian workers.' 
The second image of Justice Iacobucci is as a justice committed to building consensus on the Court by encouraging his fellow justices to reach agreement with him and with each other in deciding appeals. ${ }^{2}$ This second view also raises a series of questions. Was Justice Iacobucci the 'swing' justice on the Court in that the other justices needed to have him onside to form a winning coalition? Alternatively, was he part of a natural coalition on one side of most issues and able to persuade other, disinclined justices to join his view? Did his relative position on the Court shift depending upon the area of law at issue? Did Justice Iacobucci's leanings or preferences change over time?

This article addresses these and other related questions using an empirical analysis of Justice Iacobucci's time at the Supreme Court of Canada. It is based on a database of all Supreme Court of Canada decisions heard from the beginning of the Court year in which he was appointed, September 1990 (he was appointed on January 7, 1991), to the time he retired from the Court at the end of June 2004. In Part II, we briefly describe the database and the coding that was necessary to allow us to examine the voting records of different justices across different areas of law.

In Part III, we turn to Justice Iacobucci's voting record. We use two methods, one direct and the other indirect, to analyse how he and his fellow justices voted. The first method attempts to measure judicial preferences directly by characterizing voting in a number of areas (Aboriginal law, Charter appeals, criminal law, labour law, and tax) as either liberal or conservative, depending on the identities of the appellants and respondents. ${ }^{3}$ The second method avoids coding particular appeals and votes as

2 Tonda McCharles, 'Iacobucci, a "Giant” of a Judge, Retires' Toronto Star (22 June 2004) A16: 'He emerged as a consensus builder on the court, says Osgoode Hall dean Patrick Monahan. With now-retired Justice Peter Cory, Iacobucci rallied unanimous or often majority opinions on many contentious issues'; and Kirk Makin, 'And Coverage for All' Globe and Mail (5 June 2004) F3, quoting lawyer Mahmud Jamal as stating that Iacobucci is 'known as a deft coalition-builder. His skill in forging a consensus on the court without opening a Pandora's box would be a significant loss. For the Charter claimants, getting four votes without Justices Iacobucci and Arbour could be harder than getting five votes with them.'

3 As will be discussed in Part III, there is a considerable empirical literature in the United States coding judges' decisions as liberal or conservative. These measures are inevitably rough and imperfect but do provide some evidence of voting patterns. There are fewer empirical studies of the Supreme Court of Canada, but some have attempted to sort votes on a liberal/conservative scale. For the United States, see, e.g., Thomas J. Miles \& Cass R. Sunstein, 'Do Judges Make Regulatory Policy? An Empirical Investigation of Chevron' (2006) 73 U.Chicago L.Rev. 823; and Cass Sunstein, David Schkade, Lisa Ellman, \& Andres Sawick, Are Judges Political? An Empirical Analysis of the Federal Judiciary (Washington, DC: Brookings Institute, 2006) [Sunstein et al., Are Judges Political?]. For Canada, see, e.g., C. Neal Tate \& Panu Sittiwong, 'Decision-Making in the Canadian Supreme Court: Extending the Personal Attributes Model across Nations' (1989) 51 J.P. 4 [Tate \& Sittiwong, 'Decision-Making']; and Donald Songer \& Susan Johnson, 'Attitudinal Decision 
either 'liberal' or 'conservative' and instead uses a method popularized by Kevin Quinn and Andrew Martin involving Bayesian inference and Markov chain Monte Carlo analysis to determine the posterior distribution of the 'ideal point' (assumed to be a random variable) of each justice on a policy spectrum. ${ }^{4}$ We use both methods in conjunction to analyse how Justice Iacobucci voted in general and by area of law in relation to his colleagues on the Court. We also consider trends exhibited by the Court generally and by Justice Iacobucci specifically from 1990-1 to 2003-4. We find that, while Justice Iacobucci had a slightly more liberal voting record than did the average justice over this period, his record varied by area of law. In Charter, tax, and criminal law appeals he had a higher percentage of liberal votes than did the Court taken as a whole over this period. In Aboriginal and labour law appeals, he voted in a liberal direction less frequently than the Court as a whole. Interestingly, too, his voting record shifted significantly over his time on the bench. From 1991 to 1996, he voted in the liberal direction in just 30-40 per cent of the appeals. In contrast, in three of his last five years on the Court, he voted liberal in more than half the appeals he sat on, with his career high coming in his last term, 2003-4, when he voted liberal in 61 per cent of the appeals. Thus, towards the end of his career Justice Iacobucci was voting in a liberal direction almost twice as frequently as he was at the outset of his career. Significantly, the Court also went through a dramatic change in voting patterns over this period, with a similar though less significant shift.

In Part IV we discuss another aspect of Justice Iacobucci's record on the Supreme Court - his interaction with other justices. We begin by examining his tendency to be in the majority in split decisions. We then examine which of his colleagues he tended to agree with or disagree with overall. In the United States, there has been considerable work attempting to determine the identity of the 'median' or 'swing' justice on the Supreme Court - the justice whose vote tends to carry the day when the Court is divided. ${ }^{5}$ We posit some possibilities that are consistent with the results from our indirect (Quinn-Martin) analysis and point out implications for whether Justice Iacobucci was a consensus builder.

Part v concludes. Empirical analysis of the behaviour of justices necessarily abstracts from many important aspects of the structure, content, and

Making in the Supreme Court of Canada' (Paper presented at the Midwest Political Science Association Meetings, 2002) [unpublished] [Songer \& Johnson, 'Attitudinal'].

4 See Andrew D. Martin \& Kevin M. Quinn, 'Dynamic Ideal Point Estimation via Markov Chain Monte Carlo for the United States Supreme Court, 1953-1999' (2002) 10:2 Political Analysis 134 [Martin \& Quinn, 'Dynamic Ideal']; Andrew D. Martin, Kevin M. Quinn, \& Lee Epstein, 'The Median Justice on the United States Supreme Court' (2005) 83 N.C.L.Rev. 1275 [Martin et al., 'Median Justice'].

5 See Martin et al., 'Median Justice,' supra note 4 for a discussion of the literature on the median voter on the US Supreme Court. 
influence of the decisions of the Court. Nevertheless, we contend that such an analysis can yield interesting insights that are not possible from qualitative studies alone. ${ }^{6}$ This empirical study shows Justice Iacobucci to have been a relatively centrist justice with a slightly liberal inclination that became more prominent toward the latter part of his time on the Court. Further, his reputation as consensus builder appears to have been aided by his position as a centrist justice on the Court. It is clear from our analysis that, as a centrist with strong rates of agreement with several of his colleagues, he was able to connect strongly with justices on both the left and right sides of the spectrum.

\section{The Supreme Court of Canada database}

Before discussing our database of Supreme Court decisions, it is worthwhile, as background, to set out briefly some characteristics of the decision-making process at the Court. There are nine justices on the Court. In hearing a case, the Court sometimes sits as a unit, with all nine justices participating in the decision. More frequently, however, the Court sits in panels of five or seven justices. The Chief Justice determines the panel size and composition for each case based on a number of considerations, including (but not limited to) the nature and perceived public importance of the case, the current workload of each justice, the imminent retirement of any particular justice, and the particular legal expertise of each justice. Following oral argument, the panel holds a conference in which each justice (starting with the most junior) states his or her initial opinions. An individual justice can express an interest in writing the decision, though the Chief Justice is ultimately responsible for assigning the writing of the opinion to one or more justices. Naturally, however, the Chief Justice cannot prevent a justice from writing an opinion if she so chooses. If a justice is not in the majority, she can write a dissenting opinion alone or in conjunction with others. Further, if a justice agrees in a result with the majority but for different reasons, she can write a concurring opinion. ${ }^{7}$

6 See, e.g., Sujit Choudhry \& Claire E. Hunter, 'Measuring Judicial Activism on the Supreme Court of Canada: A Comment on Newfoundland (Treasury Board) v. NAPE' (2003) 48 McGill L.J. 525 at 533-4 [Choudhry \& Hunter, 'Measuring'], identifying some of the limitations of empirical analysis of judicial decisions (e.g., that win/loss records treat all decisions as one [no matter how important] and privilege form over substance) but arguing that, while it is important not to fall into the 'reductionist trap,' quantitative studies can aid in understanding issues that so far have been studied by legal scholars qualitatively.

7 See Ian Greene, Carl Baar, Peter McCormick, George Szablowski, \& Martin Thomas, Final Appeal: Decision-Making in Canadian Courts of Appeal (Toronto: James Lorimer, 
To analyse Justice Iacobucci's time on the Supreme Court, we created a database that took into account the institutional features of the Court, the voting record of each justice, and the potential differences across different areas of law. The database is composed of all reported Supreme Court of Canada decisions heard from the beginning of September 1990 to the end of June 2004. ${ }^{\circ}$ We coded the cases for a number of basic categories such as outcome of appeal, ${ }^{9}$ panel size, and form of contribution of each justice. ${ }^{10}$ We also categorized the appellants and respondents as one of the following: Aboriginal group, ${ }^{11}$ business, ${ }^{12}$ government, ${ }^{13}$

1998) [Greene et al., Final] for a description of the Court and its decision-making process.

8 This dataset is a subset of a larger dataset we created for a broader project on decision making on the Supreme Court of Canada. The larger dataset consists of all appeals and references with judgments rendered by the Supreme Court of Canada between 1 September 1982 and 31 August 2006. Motions, applications and interventions were not included. This information was retrieved from the Supreme Court Reports and the LexUM Web site, courtesy of the University of Montreal's Faculty of Law. Judgments that result from two appeals were indexed as one case, just as they are published. The dataset has been subject to random sampling, and no errors have been found to date. However, it is not guaranteed to be error free. Upon duplication, anomalies are most likely to arise in the categorization of type of appellant, respondent, and detailed coding. For more information on the manner of coding the decisions, please contact the authors.

9 The treatment of each case was divided into three categories: appeal allowed, appeal dismissed, and mixed and appeal allowed in part. Where possible, references were sorted into one of these three categories. Those references that were only reference questions and did not fall into one of the three categories were indicated as 'REFERENCE.'

10 For the contribution of each justice in each decision, we examined the type of participation: concurring, majority, dissenting and dissenting in part, and unanimous. We also coded whether the justice orally delivered the judgment or wrote the judgment. When no single justice had written the judgment, as in a per curium decision, no single justice received credit (there were twenty-four such judgments). When a justice was part of both majority and concurring judgment, he or she was marked as a part of the concurring judgment. When a justice was part of two different concurring or dissenting judgments, he or she was marked as having a judgment of his or her own. Justices that dissented only in the cross-appeal were considered part of the majority.

11 Includes both individuals and groups of Aboriginal descent involved in Aboriginal disputes.

12 Includes private entities (including both provincially and federally incorporated companies), individuals represented by corporations, and government-owned businesses (such as Crown corporations) that participate in open competition with other companies. Those government-owned businesses that provide services such as education and health care are not included nor are those that are essentially monopolies (e.g., Canada Post).

13 Includes all government ministries, departments, agencies, tribunals, and bodies, such as police, school boards/schools, agents of the Crown, Worker's Compensation Board, Canada Post, prisons, Child and Family Services, hospitals, and universities. 
individual, ${ }^{14}$ labour union, self-regulated organization, ${ }^{15}$ and non-governmental organization. ${ }^{16}$

In order to get a sense of whether Justice Iacobucci's role or orientation varied with the subject matter of the case, we coded the appeals according to area of law. This categorization was surprisingly challenging. There is no widely recognized way to assign appeals to categories and, indeed, appeals frequently raise multiple, loosely related issues. Difficult choices were made, based on a careful reading of the decision in each appeal and, where necessary, an analysis of the judgments of the Court of Appeal and trial court in each case. We assigned each case to at most two of the following categories:

- Aboriginal (including fishing, hunting, and land rights; fiduciary duty of Crown; constitutionality of statutes/laws under s. 35(1); and Indian Act appeals)

- Administrative (when the primary focus of the decision is on an administrative law issue such as standard of review) ${ }^{17}$

- Charter of Rights and Freedoms (encompassing all types of Charter challenge $)^{18}$

- Constitutional (including such issues as division of powers but not Charter challenges or Aboriginal issues);

- Corporate (including bankruptcy, competition law, pension law, banking, intellectual property, insurance, patents, copyright, and bills of exchange)

- Criminal (including substantive and procedural issues as well as Charter issues)

- Evidence (including both civil and criminal evidence)

- Immigration (encompassing immigration and refugee issues)

- Labour (including appeals concerning employment contracts, unions, interpretation and application of collective agreements, and arbitration)

- Municipal (including validity of bylaws and review of municipal action)

- Private (including contracts, torts, property, equity, trust, and family law)

- Procedural (encompassing civil procedure)

14 Includes estates, residents associations, community groups, and societies and committees of individuals.

15 Includes, e.g., law societies and the College of Dentistry.

16 Includes, e.g., the Canadian Council of Churches (churches) and not-for-profit organizations such as the Boys and Girls Club and Children's Foundation.

17 Administrative is also used as a secondary classification with another area of law (such as labour) where the issue primarily relates to the substantive area but also to concerns such as standard of review or procedure.

18 The only time a case is classified as primarily a different substantive area and secondarily Charter is with criminal or immigration. 
- Public (including human and civil rights [other than Charter], environmental law, unemployment insurance, maritime law, Customs Act, expropriation and communication law)

- Tax (including income tax, property tax, and Goods and Services taxes).

Since each case was assigned to up to two categories, when appeals are addressed as being criminal or Charter, it is sufficient for our purposes that one of the categories assigned corresponds to the category of appeals being considered. Thus, if an appeal was assigned to both the Criminal category and also the Charter category, it will have been included in each separate category in the results reported herein. It would also have been reasonable to make into distinctive categories those appeals raising two different areas of law. However, given the limited number of appeals heard over the time period covered by our dataset and the smallnumbers problem we are already confronted with, we felt that some double counting was preferable to mutual exclusion.

\section{From right to left: How Justice Iacobucci voted}

\section{A TWO METHODS FOR ANALYSING VOTING}

It is curious that Justice Iacobucci was appointed by Progressive Conservative prime minister Brian Mulroney but was widely perceived by the end of his tenure as a liberal member of the Court. At first glance, this difference between his record and the apparent policy preferences of the prime minister who appointed him appears to conflict with the widely accepted (particularly among political scientists) 'attitudinal' model of how justices decide appeals. The attitudinal model holds that justices' attitudes directly influence how they decide appeals. ${ }^{19}$ It does not necessarily maintain that attitudes are the sole determinant of judicial voting but it attempts to analyse how much of an effect attitudes have on justices' decisions. This effect may vary over the course of a justice's

19 Jeffrey A. Segal \& Harold J. Spaeth, The Supreme Court and the Attitudinal Model Revisited (Cambridge: Cambridge University Press, 2002) [Segal \& Spaeth, Supreme Court]; Martin et al., 'Median Justice,' supra note 4; Gregory C. Sisk \& Michael Heise, 'Judges and Ideology: Public and Academic Debates about Statistical Measures' (2005) 99 Northw.L.Rev. 743. The attitudinal model stems from work by C. Herman Pritchett, The Roosevelt Court: A Study in Judicial Politics and Values 1937-1947 (New York: Macmillan, 1948); Glendon Schubert, The Judicial Mind: The Attitudes and Ideologies of Supreme Court Justices, 1946-1963 (New York: Northwestern University Press, 1965); Glendon Schubert, The Judicial Mind Revisited: A Psychometric Analysis of Supreme Court Ideology (Oxford University Press, 1974); David W. Rohde \& Harold J. Spaeth, Supreme Court Decision Making (San Francisco: W.H. Freeman, 1976). 
career and may vary according to area of law. The attitudinal model is related to a rational choice model of judging, in which justices vote strategically to satisfy their preferences. In a strategic model, justices do not directly vote in accordance with their preferences but instead consider the impact their votes will have on either other justices on the Court or other institutions, such as the legislature. ${ }^{20}$ Both the attitudinal and strategic models can be contrasted with a conventional 'legal' model, in which justices are believed to faithfully and conscientiously attempt to apply precedent and accurately and sensibly interpret and apply legislation. ${ }^{21}$ The 'legal' view does not, of course, deny that legislation or precedent may be unclear or ambiguous. However, in appeals involving difficult legal questions, justices are assumed to interpret the legislation in a way that is most consistent with the aims of the statute or case law regarded as a whole. That is, in gap filling, they resort to known aspects of the legal order rather than their own policy preferences.

The empirical literature in the United States appears to support the attitudinal model at the federal courts of appeal and at the United States Supreme Court. ${ }^{22}$ There have been fewer empirical studies in Canada. ${ }^{23}$ The Canadian empirical studies have used a number of factors as a proxy for the ideology or policy preferences of a particular justice, including the party of the prime minister appointing the justice. These studies have tended to find that party of the appointing prime minister is one of the attitudinal factors influencing voting by particulars justice, although it is not the only influential factor. ${ }^{24}$

20 See Segal \& Spaeth, Supreme Court, supra note 19, describing the three models of judging (attitudinal, rational choice, and legal) and discussing the differences between them. Theoretical research on the strategic model of judging has increased significantly in recent years; see Lee Epstein \& Jack Knight, The Choices Justices Make (Washington, DC: CQ Press, 1998); William N. Eskridge, Jr., 'Overriding Supreme Court Statutory Interpretation Decisions' (1991) 101 Yale L.J. 331; and Forrest Maltzman, James F. Spriggs, II, \& Paul J. Wahlbeck, Crafting Law on the Supreme Court: The Collegial Game (Cambridge, UK: Cambridge University Press, 2000).

21 Segal \& Spaeth, Supreme Court, supra note 19.

22 Ibid.; Sunstein et al., Are Judges Political? supra note 3; Martin et al., 'Median Justice,' supra note 4.

23 Several studies have argued that there is a connection between political attitudes and voting patterns on the Supreme Court; see, e.g., Greene et al., Final, supra note 7; and Songer \& Johnson, 'Attitudinal,' supra note 3, summarizing some of the literature on judicial attitudes.

24 See Tate \& Sittiwong, 'Decision-Making,' supra note 3, examining Supreme Court decisions from 1949 to 1958 and finding that justices appointed by liberal prime ministers have more liberal career voting patterns; and Songer \& Johnson, 'Attitudinal,' supra note 3, extending Tate \& Sittiwong, 'Decision-Making,' supra note 3 to 2000, and finding that ideology played a role in voting, although gender and region of origin also played a significant role. See Thaddeus Hwong "A Review of Quantitative Studies of Decision Making in the Supreme Court of Canada” (2004) 
We have taken two separate approaches to analysing the Supreme Court of Canada over the course of Justice Iacobucci's tenure. Both of these approaches are consistent with the attitudinal model. Thus, the assumption common to both our approaches is that justices make decisions that are consistent with their own personal policy preferences. However, the two approaches reflect different ways of attempting to identify the policy preferences expressed by justices in their decision making. The first approach isolates appeals by areas of law that are amenable to characterization as conservative and liberal and then analyses the decisions individual justices make in these appeals. This method can be called the direct method in that it uses information about the nature of the appeals to assign liberal-conservative labels to the decisions justices make. ${ }^{25}$ We rely on an approach to coding that has been used in recent studies of judicial attitudes in the United States. ${ }^{26}$ We selected five areas as appropriate for this direct method of assessing judicial attitudes: (a) Charter appeals (where a vote in favour of the claimant is considered to be liberal, and a vote in favour of the government is considered to be conservative); (b) criminal appeals (where a vote in favour of the defendant is considered to be liberal, and a vote in favour of the prosecution is considered to be conservative); (c) labour appeals (where a vote in favour of a union, labour organization, or worker is considered to be

30 Man. L.J. 353 [Hwong, "Review"] for an overview of empirical studies of the Supreme Court of Canada, noting that the few studies that have been done have increased in sophistication.

25 One of the limitations of the dataset used in this paper is that it encompasses only appeals heard and decided by the Court. In fact, most appeals require leave to appeal to the Supreme Court. Panels of Supreme Court justices decide whether or not to grant leave to appeal, except for in the few cases where appeals are granted as of right. This process for deciding the docket of the Court provides the opportunity for a biased sample of decisions to be heard by the Court - that is, it is possible that the decision on leave to appeal could result in cases before the Court that are more or less likely to give rise to liberal or conservative votes by justices. For a discussion of this limitation on studies of the Supreme Court of Canada, see Choudhry \& Hunter, 'Measuring,' supra note 6 at 556. Further, there may be bias in voting records because the Chief Justice decides the size (five, seven, or nine justices) and composition of the panel hearing a particular case. See, e.g., Lori Hausegger \& Stacie Haynie, 'Judicial Decisionmaking and the Use of Panels in the Canadian Supreme Court and the South African Appellate Division' (2003) 37:3 Law \& Soc'y.Rev. 635, discussing the potential bias in the selection of the composition of the panel by the Chief Justice. We cannot test for such selection issues in this paper but leave these questions for future research.

26 See, e.g., Sunstein et al., Are Judges Political? supra note 3 at 17, n. 5, 48, \& 19, coding as liberal any vote to grant a defendant relief in a criminal appeal, to uphold an environmental regulation, or to uphold a decision in favour of a union against a challenge by industry or in favour of an individual bringing a claim of discrimination. For Canada, see, e.g., Tate \& Sittiwong, 'Decision-Making,' supra note 3; and Songer \& Johnson, 'Attitudinal,' supra note 3. 
liberal, and a vote in favour of an employer or business interest is considered to be conservative); (d) tax appeals (where a vote in favour of the government is considered to be liberal, and a vote in favour of the taxpayer is considered to be conservative); and (e) Aboriginal appeals (where a vote in favour of an Aboriginal group or individual is considered to be liberal, and a vote in favour of the government is considered to be conservative).

The analysis in this article differs from that in the prior empirical studies of the Supreme Court of Canada and the voting records of justices. ${ }^{27}$ First, we use actual votes as the dependant variable, unlike prior studies, which used the career voting patterns of justices (that is, the percentage of appeals in which the justice voted in a 'liberal' manner).$^{28}$ Using actual votes makes analysing the interaction between particular justices and case context more sensitive than is possible using aggregate career voting patterns in an area of law. Second, prior studies used extremely broad categorizations of areas of law (civil rights, criminal, and economic) that, relative to our approach, may decrease the sensitivity of the results to legal fundamentals. As seen in Part II, we based our analysis on more detailed categorizations, which allowed a closer examination of whether there was a tie between attitudes and particular areas of law. Third, our coding of liberal votes was slightly different - we coded as liberal a decision that upheld a government action in the face of a Charter challenge by a business. Finally, we included both unanimous and non-unanimous decisions, whereas prior studies included only non-unanimous decisions. Unanimous decisions contain considerable information about the willingness of justices to vote in particular ways, particularly since, as the highest court, the Supreme Court of Canada can overrule its own prior decisions either directly or indirectly. ${ }^{29}$

27 See, e.g., Tate \& Sittiwong, 'Decision-Making,' supra note 3; Songer \& Johnson, 'Attitudinal,' supra note 3; C.L. Ostberg, Susan Johnson, Donald Songer, \& Matthew Wetstein, 'The Nature and Extent of Attitudinal Decision Making in the Supreme Court of Canada' (Paper presented at the Annual Meeting of the American Political Science Association, 2 September 2004) [unpublished] [Ostberg et al., 'Nature and Extent']; and Ostberg \& Wetstein, "Dimensions of Attitudes Underlying Search and Seizure Decisions of the Supreme Court of Canada" (1998) 31(4) Can.J.Pol.Sc. 767.(1998); see Hwong, "Review," supra note 24, for an overview of empirical studies of the Supreme Court of Canada.

28 See, e.g., Tate \& Sittiwong, 'Decision-Making,' supra note 3; Songer \& Johnson, 'Attitudinal,' supra note 3 at $12-3$.

29 Songer \& Johnson, 'Attitudinal,' supra note 3, argue that non-unanimous decisions are a good proxy for appeals in which justices had no prior restraint on voting their preferences. Similarly, Tate \& Sittiwong, 'Decision-Making,' supra note 3 at 902, argue that unanimous appeals add no helpful information to explain judicial decision making. However, unanimous decisions are not a good proxy for when justices have a 'choice,' as Supreme Court justices always have a choice - they can 
The second approach we use to analyse voting patterns is an indirect method developed by two American political scientists, Kevin Quinn and Andrew Martin. It was originally applied to the decision making of the Supreme Court of the United States from 1953 to 1999. ${ }^{30}$ Because of similarity in the institutional features of the two courts, it is equally applicable to an analysis of the decision making of the Supreme Court of Canada. The Quinn-Martin approach does not directly impose a liberal-conservative characterization on the appeals. Instead, the Quinn-Martin approach assumes only that each case can be represented in policy space as falling somewhere on a line running from $-\infty$ to $+\infty$. There are no assumptions made about the content of this policy space, and no appeals have been arbitrarily left out of the analysis. ${ }^{31}$ Armed with this assumption of one-dimensionality, the Quinn-Martin approach then assumes that the legal strength of each case means that it can be situated somewhere on this spectrum, such that justices whose policy preferences are to the left of that point will be persuaded that the case should be decided one way, while justices to the right of that point will be persuaded that the case should be decided the opposite way. Using these assumptions, the method considers all of the informative decisions all of the appeals in which the justices disagree about the result - and posits that the differing outcomes reflect the fact that the legal strength of the case on the continuum separates those justices who would allow the appeal from those who would dismiss the appeal. Notably, because concurring reasons reach the same outcome (i.e., allow or dismiss), there is no difference in the coding of concurring opinions and majority opinions. ${ }^{32}$

Given the data on how justices split on decisions, the Quinn-Martin method uses a Markov Chain Monte Carlo process to estimate the posterior distribution of the ideal points of the justices on a one-dimensional spectrum . The ordinal ranking of the justices is meaningful, as are the distances between justices and the breadth of each justice's ideal-point

overrule even their own prior decisions. Given the high proportion of appeals in each term that are unanimous, omitting unanimous decisions excludes a considerable amount of information on voting patterns.

30 Martin \& Quinn, 'Dynamic Ideal,' supra note 4.

31 Unanimous appeals are uninformative when using this methodology, however, because unanimity signals that the legal merits of the case are so clear that a case is to the left or to the right of all the justices.

32 This reflects the assumption that the most reliable information about a judgment is the outcome reached in the case. Some might plausibly argue that concurring opinions provide information about justices' preferences. We would not necessarily disagree but would hasten to point out that justices may have other reasons for authoring separate opinions reaching the same result (relatively unimportant differences in legal reasoning, reluctance to decide issues not squarely raised by an appeal, etc.). 
distribution, which together give an indication of how likely particular justices are to agree in a given case. However, whether a justice is assigned a negative value or a positive value is meaningless when considered in isolation, since there are no assumptions about the appeals other than that they exhibit unidimensionality and that it is meaningful when justices reach different outcomes. Nevertheless, if one insists on labelling the different poles of the undefined policy space, this can be done relatively easily ex post by examining the justices who are at the extremes of the spectrum, along with other information about the justices, such as that gleaned from our direct method of analysis of judicial voting.

In our dataset, over the period Justice Iacobucci was on the Court, there were 332 appeals with a divided panel. We use the Quinn-Martin technique to analyse the combined dataset of all 332 split decisions, a dataset consisting of 96 split-panel appeals involving Charter issues and a dataset of 158 split-panel appeals raising criminal issues. There were too few split-panel Aboriginal, labour, or tax appeals over this period to permit the Quinn-Martin method to be applied successfully to these categories separately. ${ }^{33}$

\section{B THE OVERALL RECORD}

As noted above, by the end of his time on the Court, Justice Iacobucci was viewed as being a liberal. Examining his voting over all five areas of law using the direct method shows that he voted liberal a slightly higher percentage of the time than did his colleagues. Justice Iacobucci's liberal voting percentage for decisions over all five areas of law was 39.9 per cent, while the average for the other justices was 37.7 per cent. This means that both Justice Iacobucci and, on average, the other justices on the Court in this period voted liberal, according to our definition, nearly two fifths of the time (Table 1). Justice Iacobucci's liberal voting percentage was not significantly different from that of Justice Lamer, who, for the purposes of this analysis, had approximately the median percentage of voting liberal. ${ }^{34}$ As Table 1 shows, there were a number of justices who were significantly different from Justice Lamer both on the liberal side (Justices Fish, Arbour, and Deschamps) and on the conservative side (Justices L'Heureux-Dubé and Gonthier). From this perspective, Justice Iacobucci was slightly on the liberal side of a fairly conservative Court.

33 Technically speaking, a small number of observations tends to lead to a failure of the algorithm to converge on robust ideal-point estimates for the justices.

34 We ran an OLS regression with the votes of the justices as the dependent variable and dummy variables for each justice except one. We determined that Lamer was the median on this measure. We then re-ran the regression with Lamer as the default justice. On this regression (and the prior regression), the coefficient for Iacobucci was not statistically significant. 
TABLE 1

Liberal voting - Percentages of justices (September 1990-June 2004) ${ }^{\mathrm{a}}$

\begin{tabular}{llllllc}
\hline Justice & All appeals & Aboriginal & Charter & Criminal & Labour & Tax \\
\hline L'Heureux-Dubé & $28.1^{*}$ & 47.6 & $26.8^{*}$ & $18.1^{*}$ & 66.0 & 20.0 \\
Gonthier & $31.1^{*}$ & 32.1 & $30.7^{*}$ & $26.1^{*}$ & 54.7 & 26.3 \\
La Forest & $33.6^{* *}$ & 27.8 & 36.6 & $29.5^{* *}$ & 50.0 & 27.8 \\
Bastarache & 34.3 & 30.0 & 32.2 & 31.5 & 48.3 & 31.8 \\
McLachlin & 35.6 & 41.4 & 35.1 & $31.0^{* *}$ & 57.7 & 21.2 \\
Cory & 38.1 & 42.9 & 38.5 & 32.8 & 61.8 & $43.5^{* *}$ \\
Stevenson & 39.1 & 33.3 & 46.7 & 34.7 & 50.0 & $\mathrm{~N} / \mathrm{A}$ \\
Lamer & 39.8 & 31.8 & 42.1 & 36.6 & 50.0 & 12.5 \\
Iacobucci & 39.9 & 36.0 & 39.2 & 37.1 & 53.8 & 29.3 \\
Sopinka & 40.9 & 41.2 & 37.2 & 38.7 & 51.9 & 35.7 \\
Major & 42.3 & 26.1 & 38.5 & $43.6^{*}$ & 47.5 & 25.8 \\
Binnie & 42.4 & 50.0 & 46.2 & 40.7 & 56.5 & 25.0 \\
LeBel & 45.1 & 37.5 & 47.9 & $46.6^{* *}$ & 47.1 & 33.3 \\
Deschamps & $52.1^{*}$ & 50.0 & 45.8 & $54.3^{*}$ & 44.4 & $100.0^{* *}$ \\
Arbour & $53.8^{*}$ & 33.3 & $61.5^{*}$ & $53^{*}$ & 59.1 & 28.6 \\
Fish & $62.5^{*}$ & 50.0 & 45.5 & $77.8^{*}$ & 50.0 & $100.0^{* *}$ \\
Court Average & 37.7 & 36.9 & 37.3 & 34.2 & 54.7 & 28.0 \\
\hline
\end{tabular}

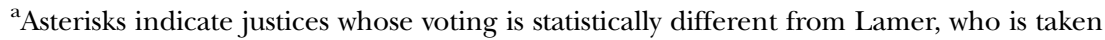
as the median; * indicates significance at a $95 \%$ level, ** significance at a $90 \%$ level.

Turning to the indirect method, the most robust use of the QuinnMartin method makes use of all 332 split-panel decisions of the Court over the period. For the purposes of this analysis, the 332 split-panel decisions are treated as if they occurred contemporaneously. In other words, the analysis proceeds on the assumption that all of these justices were on the Court at the same time but that panels of five, seven, or nine of them were assigned to each appeal. This provides us with the ability to compare directly the policy positions of each of the fifteen justices who ever served on the Court with Justice Iacobucci, even if they never served together. For contrast, Figure 1 depicts the estimated ideal points of the justices of the United States Supreme Court for the 2000 term, plotted from -4 to +4 . Figure 2 shows similar estimates for the Supreme Court of Canada for appeals heard during the period January 1991 to June 2004, also from -4 to +4 . The corresponding estimated ideal points, along with the standard deviations, are reported in Table 2.

It is apparent from both Figure 2 and Table 2 that Justice Iacobucci was near the centre of the Court over the course of his career. His estimated ideal point, taking all appeals into account, is 0.42 , which puts him adjacent to Justice Binnie (0.37), who, along with Justice Cory (0.28), 


\section{FIGURE 1}

Estimated ideal points of the United States Supreme Court (2000 term). Source. Andrew D. Martin \& Kevin M. Quinn, 'Applied Bayesian Inference in R using MCMCpack' < http:// www.people.fas.harvard.edu/ kquinn/papers/Rnews05.pdf $>4$; printed with permission.

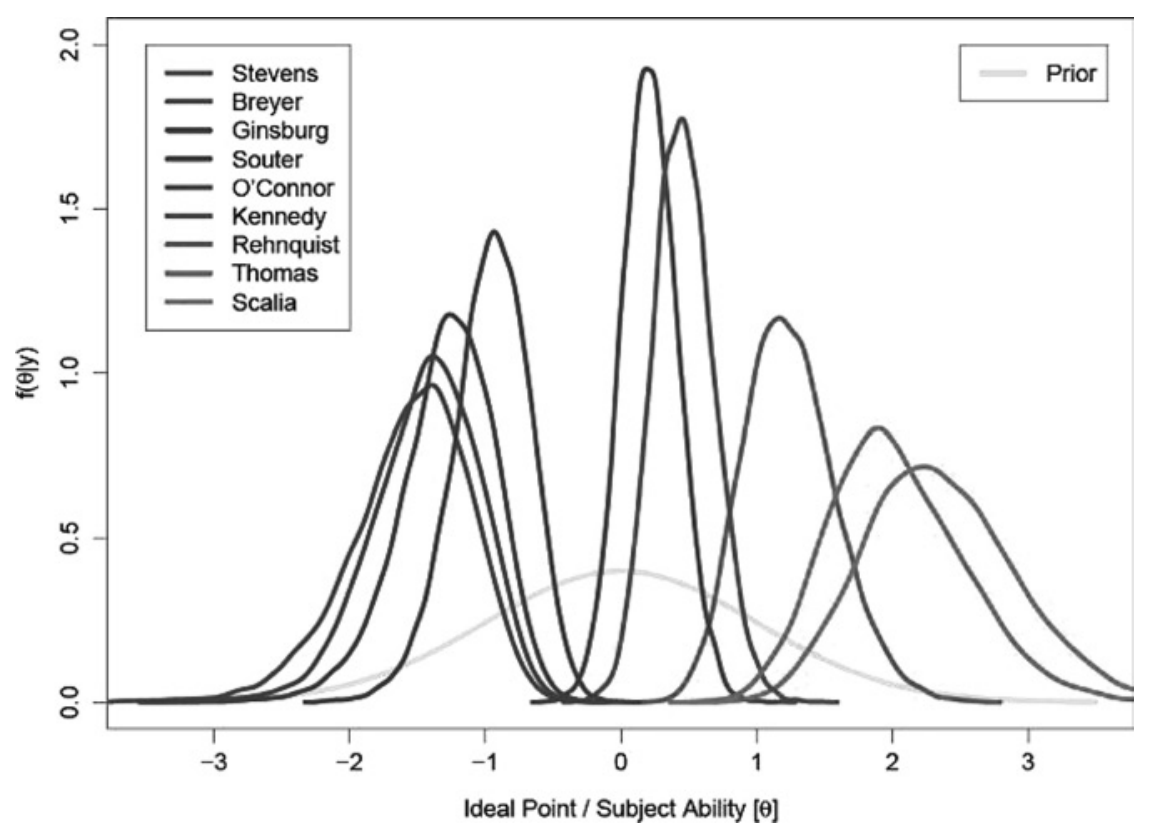

define the median of the sixteen justices who served on the Court from 1991 to 2004. Since the standard deviation of Justice Iacobucci's estimated ideal point is approximately 0.10 , he is not significantly different from Justices Binnie or Cory and thus not significantly different from the median of the Court. This result is entirely consistent with the finding reported in Table 1 that Justice Iacobucci voted liberal 39.9 per cent of the time versus the Court's 37.7 per cent over the same time period. That Justice Iacobucci is assigned a slightly higher ideal point than the median justices is also consistent with the perception of Justice Iacobucci as a liberal justice. Taken together, these two indicators of Justice Iacobucci's inclinations while he was on the Court provide evidence that he was, indeed, a justice who was slightly left of the centre.

Interestingly, from Figures 1 and 2 and Table 2 some basic conclusions can be drawn about the differences between the Supreme Court of Canada (SCC) and the United States Supreme Court (USSC). The most striking difference is the wide dispersion in policy space of the justices of the USSC as compared with the clustering exhibited by the justices of the SCC. With the exceptions of Justices L'Heureux-Dubé $(-2.45)$, 
FIGURE 2

Estimated ideal points, SCC, all appeals (January 1991-June 2004)

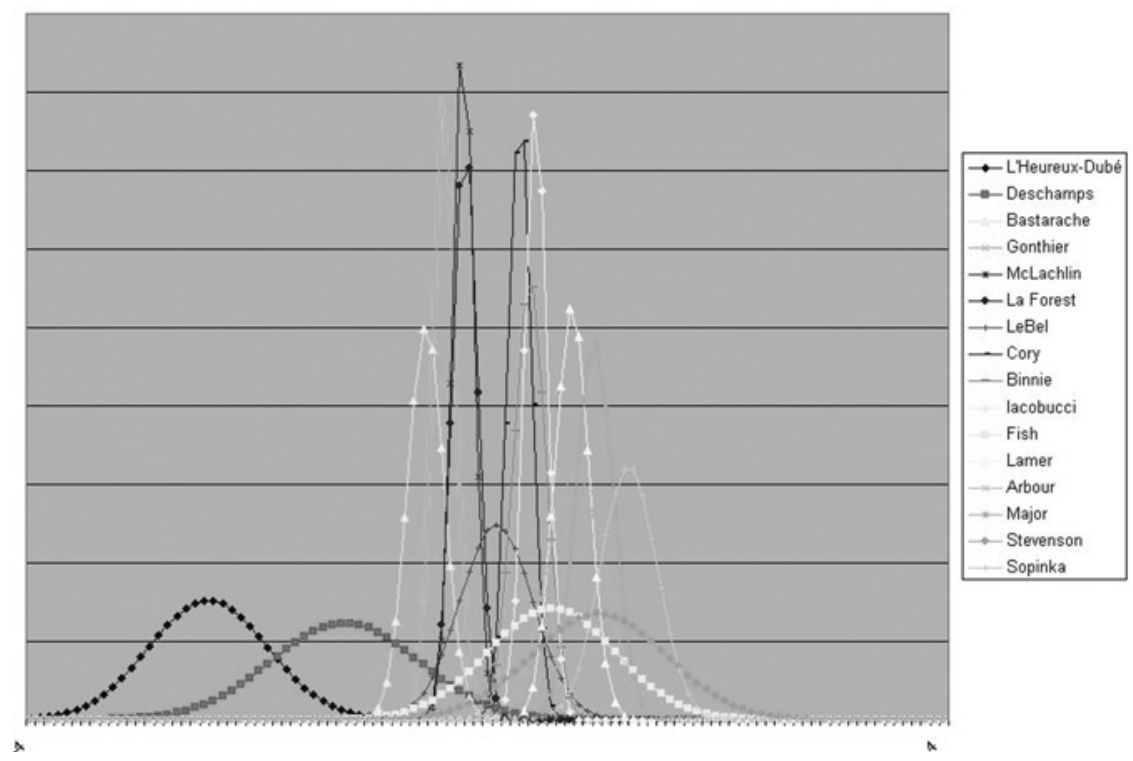

Deschamps (-1.25), and Sopinka (1.24), all the justices on the SCC are within the range of -1 and +1 . And of the three outlier Canadian justices, Justice L'Heureux-Dubé's estimated ideal point is nearly twice as far from 0 as are those of Justices Deschamps and Sopinka. By way of contrast, on in the case of the USSC for the 2000 term, Quinn and Martin show that only three justices - Souter, O'Connor, and Kennedy - are estimated to be within the range of -1 and +1 . This result is even more interesting when one recognizes that the dispersion reported in estimated ideal points for the USSC resulted from only one year of appeals, which leaves relatively few cases to move the justices from the assumed uninformative priors to their estimated ideal points. All else being equal, it would have been reasonable to expect the estimated ideal points of the SCC justices to have drifted further from the assumed uninformative priors. That the result is so striking in the opposite direction suggests either that the justices on the SCC are much more alike in their political attitudes than are their colleagues on the USSC or that the justices of the SCC are behaving more in keeping with a formal legal model of adjudication or consensus building within the Court rather than simply indulging their policy preferences in isolation from each other in reaching their decisions, as seems to be suggested by the results of ideal-point estimation for justices of the USSC.

One of the curious things about this set of results from the ideal-point estimation is that Justice L'Heureux-Dubé is estimated to be such an 
TABLE 2

Estimated ideal points, SCC, all appeals (January 1991-June 2004)

\begin{tabular}{lrl}
\hline Justice & Mean & Standard deviation \\
\hline L'Heureux-Dubé & -2.45 & 0.52 \\
Deschamps & -1.25 & 0.65 \\
Bastarache & -0.54 & 0.16 \\
Gonthier & -0.38 & 0.10 \\
McLachlin & -0.21 & 0.09 \\
La Forest & -0.20 & 0.11 \\
LeBel & 0.08 & 0.32 \\
Cory & 0.28 & 0.10 \\
Binnie & 0.37 & 0.14 \\
Iacobucci & 0.42 & 0.10 \\
Fish & 0.57 & 0.56 \\
Lamer & 0.74 & 0.15 \\
Arbour & 0.77 & 0.25 \\
Major & 0.94 & 0.17 \\
Stevenson & 0.98 & 0.59 \\
Sopinka & 1.24 & 0.25 \\
\hline
\end{tabular}

extreme justice. This is consistent with her frequent dissenting but has strange implications for the rest of the analysis, as we will see. The confounding issue is that Justice L'Heureux-Dubé is, as revealed by the liberal voting percentages reported in Table 1 above, extremely conservative in criminal appeals (18.1 per cent liberal versus the Court average of 34.2 per cent) and significantly conservative in Charter (28.1 per cent liberal versus the Court average of 37.3 per cent) and tax appeals (20 per cent versus 28 per cent liberal for the Court), while at the same time being quite liberal in Aboriginal (47.6 per cent versus 36.9 per cent liberal for the Court) and labour (66 per cent versus 54.7 per cent liberal for the Court) appeals. This suggests that there may be noise in this overall ranking of justices, since the ideal-point estimation proceeds on the assumption that all appeals are created equally and that the ordering of justices should not depend on the underlying area of law. Further, the correlation among the estimated ideal points with liberal voting percentages in all five areas taken together is 0.38 . In Charter appeals, the correlation is 0.50 , and in criminal appeals, it is 0.38 . Troublingly, however, the correlations among the estimated ideal-point scores and the percentages of liberal votes in the other appeals are negative. For Aboriginal appeals, the correlation is -0.34 , for labour appeals, the correlation is -0.30 , and in tax appeals, the correlation is -0.09 . Consequently, more faith should likely be placed in the more specific results obtained when the sample is reduced only to Charter appeals or 
criminal appeals, the results of which are reported in Tables 3 and 4 (see later), than in these more general findings.

These results suggest that decisions made by the justices are not driven by an underlying attitude that is distributed unidimensionally. There are several possible explanations. One obvious potential source of error is that the properties of the appeals heard by the Court were not held consistent over the time period, with the result that the assumption of contemporaneousness has distorted the estimates. A related explanation would be that there was a violation of the assumption that the preferences of the justices do not change over time. Yet another potential problem is that, even if justices were deciding appeals on the basis of personal attitudes or policy inclinations, such inclinations would not necessarily match conventional understandings of conservative-liberal politics there may be additional dimensions of attitudes or competing ways of conducting the direct analysis that would better correlate with the results from the indirect method.

\section{VOTING BY AREA OF LAW}

Justice Iacobucci's overall voting record may conceal significant differences in his voting across areas of law. For example, Songer and Johnson examined non-unanimous Supreme Court of Canada decisions between 1985 and 2000. They divided the appeals into three categories:

TABLE 3

Estimated ideal points, SCC, Charter appeals (January 1991-June 2004)

\begin{tabular}{lcl}
\hline Justice & Mean & Standard deviation \\
\hline L'Heureux-Dubé & -1.87 & 0.51 \\
Gonthier & -0.51 & 0.19 \\
Bastarache & -0.47 & 0.30 \\
McLachlin & -0.37 & 0.19 \\
La Forest & -0.22 & 0.19 \\
Deschamps & 0.03 & 0.76 \\
Binnie & 0.39 & 0.27 \\
Iacobucci & 0.42 & 0.19 \\
Major & 0.47 & 0.21 \\
Stevenson & 0.52 & 0.54 \\
Cory & 0.52 & 0.23 \\
LeBel & 0.54 & 0.35 \\
Arbour & 0.77 & 0.43 \\
Sopinka & 0.79 & 0.29 \\
Fish & 1.06 & 0.77 \\
Lamer & 1.14 & 0.41 \\
\hline
\end{tabular}


TABLE 4

Estimated ideal points, SCC, criminal appeals (January 1991-June 2004)

\begin{tabular}{lll}
\hline Justice & Mean & Standard deviation \\
\hline L'Heureux-Dubé & -2.70 & 0.53 \\
Gonthier & -0.82 & 0.18 \\
Bastarache & -0.73 & 0.24 \\
Deschamps & -0.54 & 1.09 \\
McLachlin & -0.41 & 0.14 \\
La Forest & -0.32 & 0.16 \\
LeBel & 0.05 & 0.23 \\
Fish & 0.25 & 1.02 \\
Binnie & 0.35 & 0.20 \\
Cory & 0.35 & 0.15 \\
Iacobucci & 0.36 & 0.14 \\
Stevenson & 0.72 & 0.56 \\
Lamer & 1.03 & 0.25 \\
Sopinka & 1.30 & 0.30 \\
Major & 1.34 & 0.29 \\
Arbour & 2.09 & 0.59 \\
\hline
\end{tabular}

(a) civil rights and liberties appeals, (b) criminal appeals, and (c) economic appeals. Songer and Johnson found that certain factors, such as gender, made a difference depending on the area of law. More specifically, female justices tended to have more liberal voting records on civil liberties appeals but to not vote significantly differently than male justices in criminal or economic appeals. Further, they found that Ontario justices had a more liberal voting record in civil liberties and criminal appeals. ${ }^{35}$ In light of the results of Songer and Johnson and the general intuition that a justice's attitudes in one area of the law might not necessarily map perfectly onto the same justice's attitudes in other parts of the law, ${ }^{36}$ it is important to analyse whether Justice Iacobucci's voting records differed across different areas of law.

Using the direct method for analysing voting records, Justice Iacobucci's voting record in each of the five areas of law can be seen to be close to the average for all justices, with a slightly higher-thanaverage liberal voting record in Charter, criminal, and tax appeals, and

35 See Songer \& Johnson, 'Attitudinal,' supra note 3; as noted above, unlike the present study, Songer and Johnson rely more on both more crude categories of appeals and aggregate (career) voting patterns than on votes in individual appeals.

36 E.g., the fact that one is generally in favour of the rights of the accused in criminal appeals might not necessarily imply that one would be more likely to side with unions or workers in labour law disputes. 
FIGURE 3

Liberal Voting, 1990-2004 (percentage)

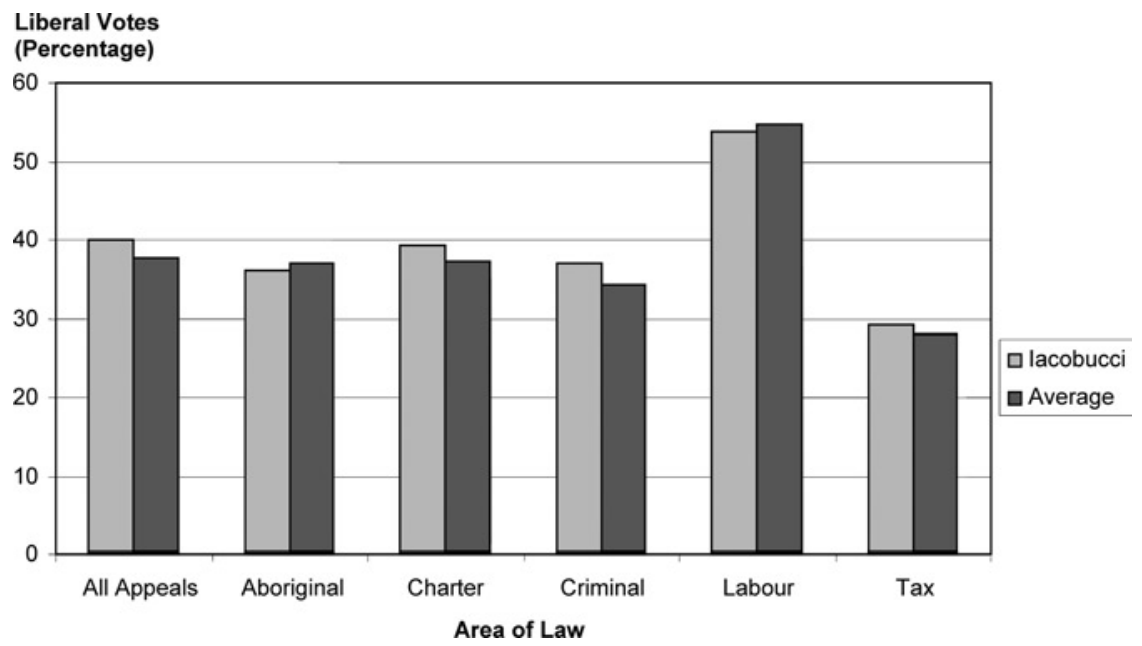

a slightly lower-than-average liberal voting record in Aboriginal and labour appeals (Figure 3). The percentage liberal voting record of both Justice Iacobucci and the average of all justices vary significantly over the five areas of law, from a high of over 50 per cent for labour appeals to a low of less than 30 per cent for tax appeals. However, as was the case with the overall record, Justice Iacobucci's voting record was not significantly different from that of Justice Lamer (who was taken to have the median liberal voting record) (Table 1). A number of justices were statistically significantly different from Justice Lamer in several areas of law. In Charter appeals, for example, Justices L'Heureux-Dubé and Gonthier had significantly more conservative voting records than Justice Lamer. Justice Arbour had a significantly more liberal voting record in Charter appeals. In criminal appeals, Justices L'Heureux-Dubé, Gonthier, La Forest, and McLachlin had more conservative voting records than Justice Lamer. Justices Fish, Arbour, Deschamps, LeBel, and Major had significantly more liberal voting records. The only other statistically significant differences were in tax appeals, with Justices Cory, Deschamps, and Fish being significantly more pro-government than Justice Lamer. The small number of appeals in the other areas lead to the conclusion that differences across justices were not statistically significant. As a result, this analysis shows that Justice Iacobucci's voting record was very close to the average of all justices in the period, even though the voting records varied significantly by area of law, and that he was not statistically different from Justice Lamer in any of the five areas of law considered. 
Justice Iacobucci's being close to the centre of the Court across different areas of law, as assessed by the direct method, can also be seen using the indirect method of estimating ideal points using only appeals involving individual areas of law. The only two areas with a number of split panels sufficient to arrive at robust estimates of ideal points were Charter appeals $(n=158)$ and criminal appeals $(n=96)$. As mentioned earlier, these two groups of appeals were not mutually exclusive. If an appeal raised both a Charter issue and a criminal issue, it was included in the data used to produce to both estimates.

Table 3 shows that, in Charter appeals over the period, Justices Iacobucci (0.42) and Binnie (0.39) were the median justices of the sixteen. Again, note that, although Justice Iacobucci was in the centre of the Court, he was on the left edge of centre. This is consistent with the view that Justice Iacobucci was a liberal justice in Charter appeals. All of the justices (except Justice L'Heureux-Dubé, who had an estimated ideal point of -1.87 ) had estimated ideal points with a mean well within a range of $+/-1$ of the median (i.e., between -0.60 and +1.40 ) on Charter cases. This clear effect of clustering around the median, along with the observation that the standard deviations of the estimated ideal points were relatively high, suggests strongly that the Court did not always fragment predictably on Charter appeals over the period. Again, however, the exception was Justice L'Heureux-Dubé, whose ideal point indicates that she departed dramatically from the views of her colleagues in Charter cases. The correlation between the Charter-only ideal-point estimates and the percentage liberal voting scores reveals that these ideal points are significantly more accurate than the ideal points taking into account all legal areas, reported in Table 1. The correlation between liberal votes and these ideal-point estimates is (a) all five areas together, 0.67; (b) Aboriginal, -0.08; (c) Charter, 0.69; (d) criminal, 0.65 ; (e) labour, -0.42 ; and (f) tax, 0.24 .

Table 4 shows that, according to the ideal-point estimates in criminal appeals, Justice Iacobucci was also a moderate. Although Justice Fish (0.25) and Justices Binnie and Cory (0.35) defined the centre of the Court in criminal appeals, Justice Iacobucci was just to the liberal side (0.36) of Justice Binnie, making him very nearly the median justice in criminal appeals as well. Again, the Court clustered around the median, with all of the justices (except Justices L'Heureux-Dubé, -2.70, and Arbour, +2.09 ) being within a range of $+/-1.2$ (i.e., within the range of -0.9 to 1.5). Justice L'Heureux-Dubé is an outlier on the side of the government (i.e., anti-accused's rights) in criminal appeals at - 2.70, and Justice Arbour is an outlier in favour of accused's rights at 2.09. The correlation between the criminal-only ideal-point estimates and the percentage liberal voting scores reveals that these ideal points are almost as accurate as the ideal points for Charter cases alone, reported in Table 3. The correlation 
between liberal votes and these ideal-point estimates is (a) all five areas together, 0.52; (b) Aboriginal, -0.32; (c) Charter, 0.70; (d) criminal, 0.46 ; (e) labour, -0.28 ; and (f) tax, -0.04 .

\section{VOTING OVER TIME}

The discussion of the justices' voting records overall and by area of law relies on a very strong assumption - that the attitudes of each justice remain constant over the whole period. However, one could imagine that the views of justices might change over time as a result of any number of factors. Some of the factors might include ordinary lifecycle and age effects, the result of accumulated judicial experience, losing or gaining the influence of departing and new colleagues, and changes in social attitudes more generally.

Using the direct method, Justice Iacobucci's voting record can be seen to have changed significantly in his time on the bench (Figure 4). In the first five years of his tenure on the Court, Justice Iacobucci's overall liberal voting record varied between 30 and 40 per cent (average 33.8 per cent), his lowest percentage liberal voting term being his second full year on the bench, 1992-3, when he voted liberal in just 30 per cent of the appeals on which he sat. By his last five years on the bench, his liberal voting record had increased to approximately 50 to 60 per cent (average 52.8 per cent). The term with his highest percentage liberal voting (more than 60 per cent) was his last term. It is remarkable that in 2003-4, Justice Iacobucci voted liberal at more than twice the rate he did in 1992-3.

Interestingly, while Justice Iacobucci changed significantly over the period, so too did the Court. The average percentage liberal voting rate for the Court followed a similar path to that of Justice Iacobucci's voting (Figure 4). The rate of increase over the period for the Court was 0.5 per cent per annum - a significant rate of increase over the period. ${ }^{37}$ Why did the voting rates of both Justice Iacobucci and the Court change so much over the period? Did either or both shift their preferences over time towards more liberal views or was something else going on? One possibility is that the change in voting records came about because of changes in the Court. With just one early exception, the first half of Justice Iacobucci's time on the Court was a natural court, in which the bench stayed the same for a period of time and no justices left or joined. From the time of Justice Iacobucci's appointment until

37 We ran a time-trend variable with the dummy variables for the justices, again with votes as the dependent variable. The coefficient on the time-trend variable was- -0.005 and was significant at the 95 per cent level (recalling again that in the regressions, negative is interpreted as more liberal). We do not have Quinn-Martin scores for the justices over time. This requires dynamic linear modelling, which will be part of further work on this project. 
FIGURE 4

Liberal voting, all appeals, by term

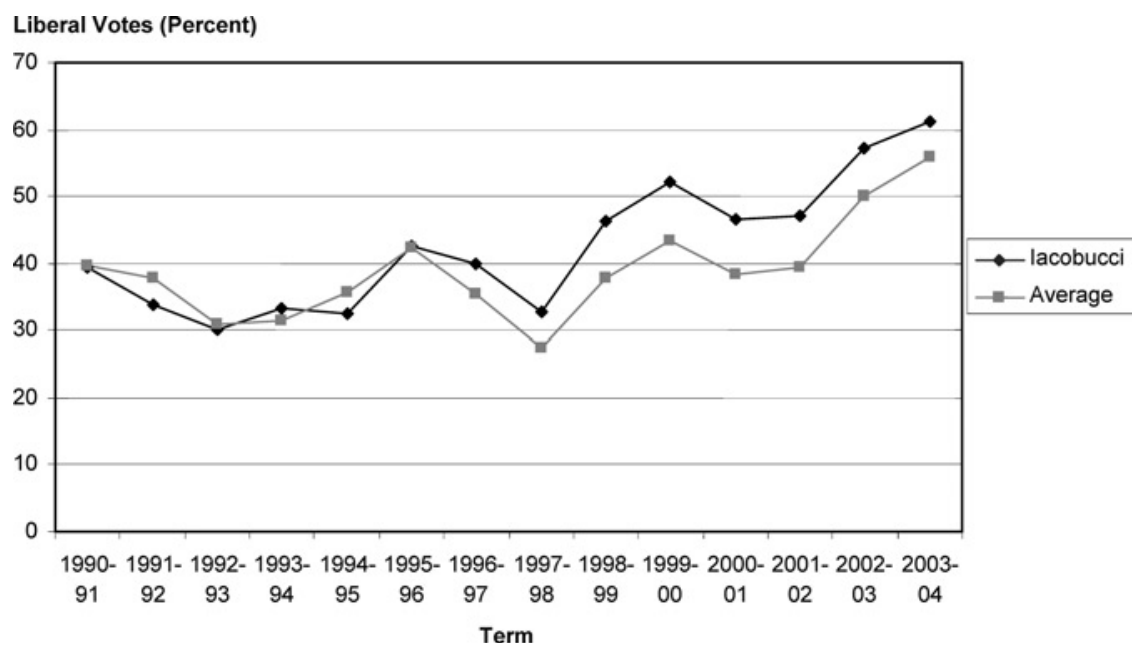

1997, there was only one change in the composition of the bench, with Justice Major replacing Justice Stevenson in 1992. Over this time period, the trend line in the voting record is fairly flat (Figure 4). However, in the second half of Justice Iacobucci's time on the bench, with a further six justices leaving and another six joining the Court, the average liberal voting rates increased significantly, from 36 per cent in the first half to 42 per cent in the second half - a rise of nearly 20 per cent in proportional terms.

The impact of the changes over the second half of Justice Iacobucci's tenure on the Court depended on whether the new justices tended to vote liberal at a higher or lower rate than did the individuals they replaced. Table 5 shows the year in which justices left or joined the bench over this period and their percentage liberal voting records. While, for some justices, their period on the bench in the period was too short to have confidence about their actual voting record (for example, Justice Fish), the changes do seem to indicate a shift towards justices with more liberal voting records. In each case, the departing justice was replaced by a justice who had a higher percentage liberal voting record, with the difference in percentage liberal voting being fairly large in the latter part of the period..$^{38} \mathrm{~A}$ similar, though not so

38 It is interesting to note that all but one of the justices who were leaving the Court at this time had been appointed by Conservative prime ministers, while the justices appointed in the latter half of the period were appointed by a Liberal prime minister. Some studies have shown a (weak) connection between the party of the prime minister 
dramatic effect, is mirrored in Table 6, which shows the changes in the estimated ideal points resulting from each departing justice's being replaced with each new justice. The largest effect in a liberal direction resulted when Justice L'Heureux-Dubé was replaced by Justice Deschamps, even though Justice Deschamps was the justice who was estimated to be the second-most conservative justice to be on the Court over the 1991-2004 period.

However, a second possible reason for the move towards greater liberal voting on the Court is that, despite the changes in the bench, the underlying preferences of the justices remained substantially the same but the mix of appeals changed, leading to differences in the voting record. The change in Court voting came mainly from shifts towards more liberal voting on criminal and Charter appeals (see Figures 5 and 6), offsetting a modest conservative shift in voting in the areas of Aboriginal and tax law and combining with a slight liberal shift in labour appeals. ${ }^{39}$ Moreover, Justice Iacobucci's voting shift in these two areas was similar to that of the Court, with a marginally greater shift for criminal appeals. There may, of course, be a variety of reasons for this shift in voting, including a change in the voting preferences of the justices, a change in the membership of the bench, or a change in the type of appeals within each category. However, these results indicate that the shift arose from changes not in the proportion of appeals in each category (that is, more of a type of appeals where voting was more liberal) but in the proportion of appeals in the criminal and Charter categories in which the justices vote liberal.

The voting record of both Justice Iacobucci and the Court, therefore, changed significantly over the period. It is difficult to determine from this analysis whether Justice Iacobucci changed his preferences and was able to shift the Court along with him or the Court changed and Justice Iacobucci changed with it. As noted above, one important

appointing a justice and her voting record (see, e.g., Tate \& Sittiwong, 'DecisionMaking,' supra note 3; and Songer \& Johnson, 'Attitudinal,' supra note 3). We are currently working on a project that examines this issue in more detail. Note that the voting record for Fish is based on a very short time on the Court.

39 Figures 3 and 4 do not include the other areas of law (Aboriginal, labour, and tax), as there were too few appeals to get a clear view of a trend. We ran regressions that included the time-trend variable and the justice variables as well as variables for the area of law and variables for the interaction between the area of law and the time trend. We found that the trend variable was estimated at -0.021 (criminal significant at the 95 per cent level) and the interaction variable for Charter appeals was 0.006 (but not significant at the 90 per cent level), for Aboriginal appeals was 0.029 (significant at the 95 per cent level), for tax was 0.036 (significant at the 95 per cent level), and for labour was 0.018 (significant at the 95 per cent level). Note that a negative coefficient means more liberal and that the interaction variables are changes from the time trend. 
218 UNIVERSITY OF TORONTO LAW JOURNAL

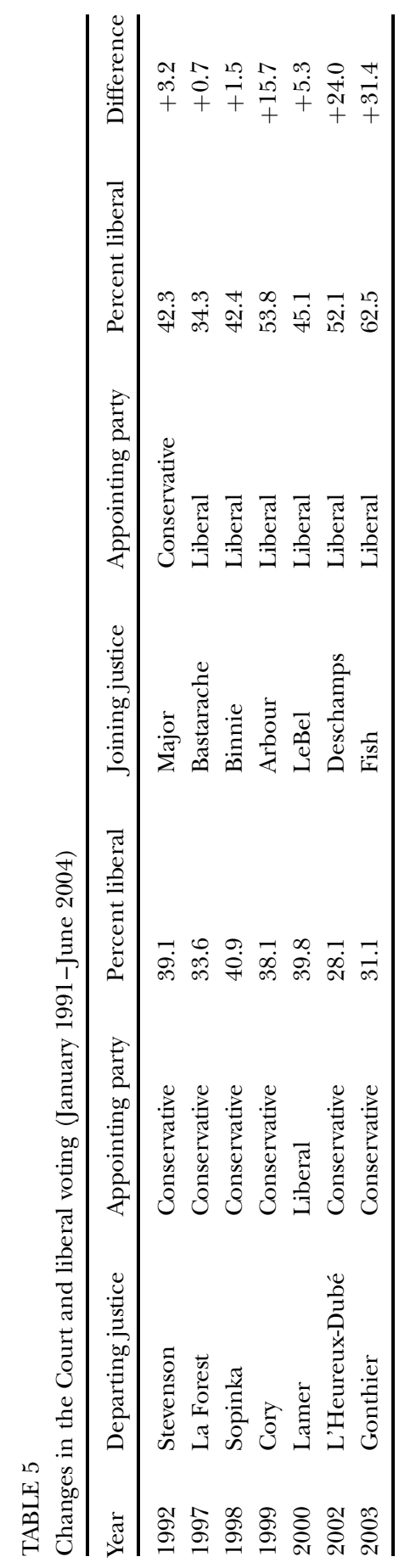


THE REASONABLE JUSTICE 219

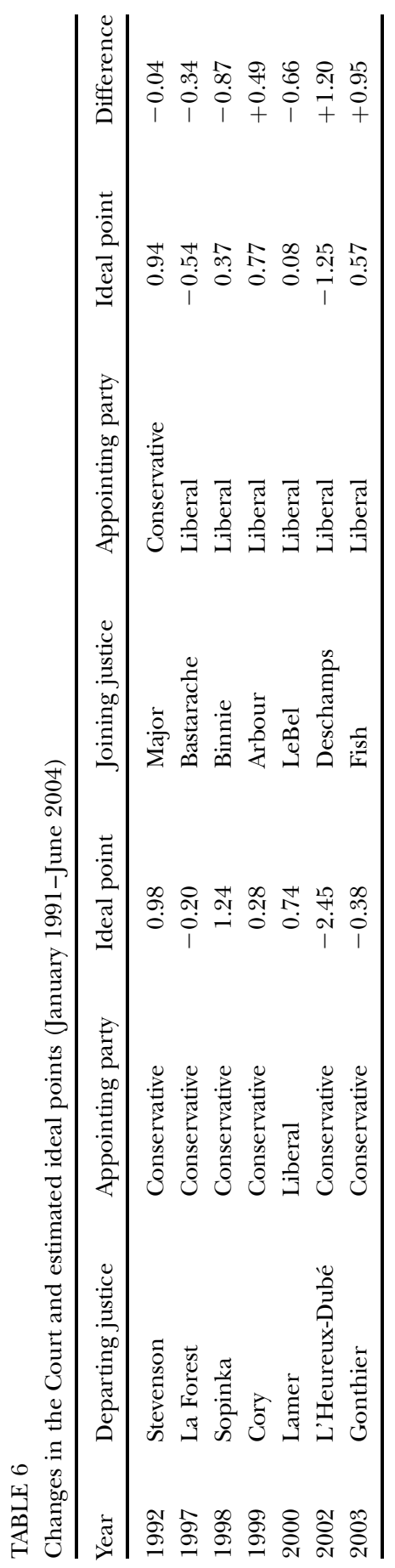


FIGURE 5

Liberal voting, Iacobucci, Charter (1990-2004)

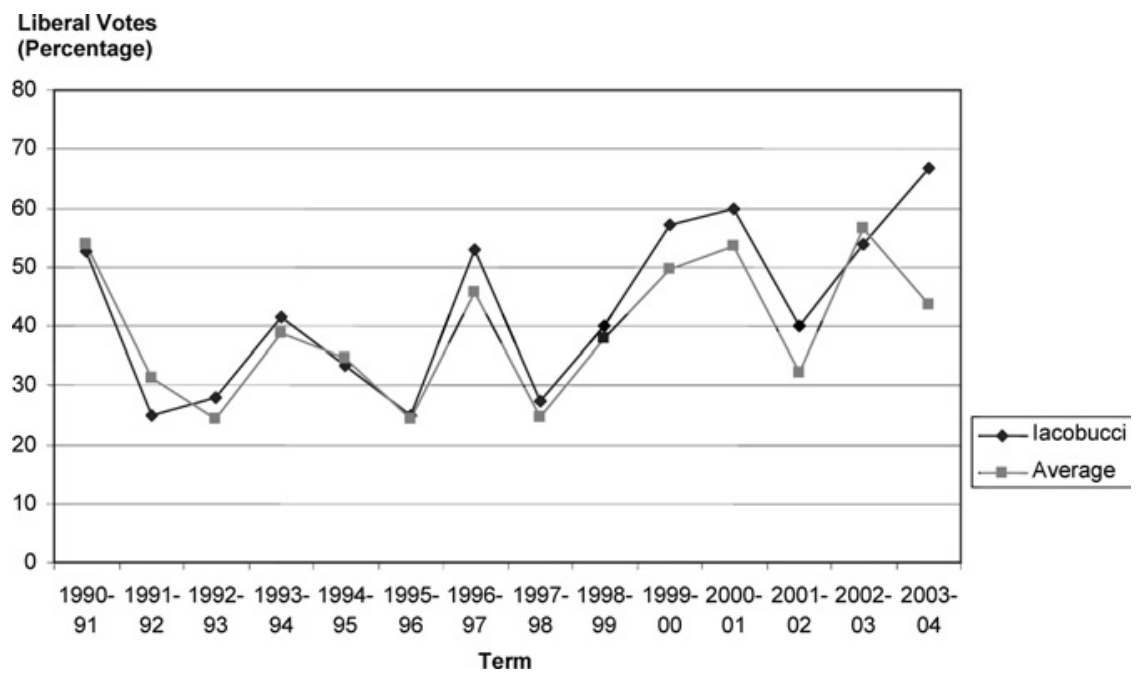

factor in assessing changing voting patterns on the Court is the composition of the bench. As the composition of the bench changed, so too did average voting records. However, there is something else, beyond personal preferences, that may affect voting records as

FIGURE 6

Liberal voting, Iacobucci, Criminal (1990-2004)

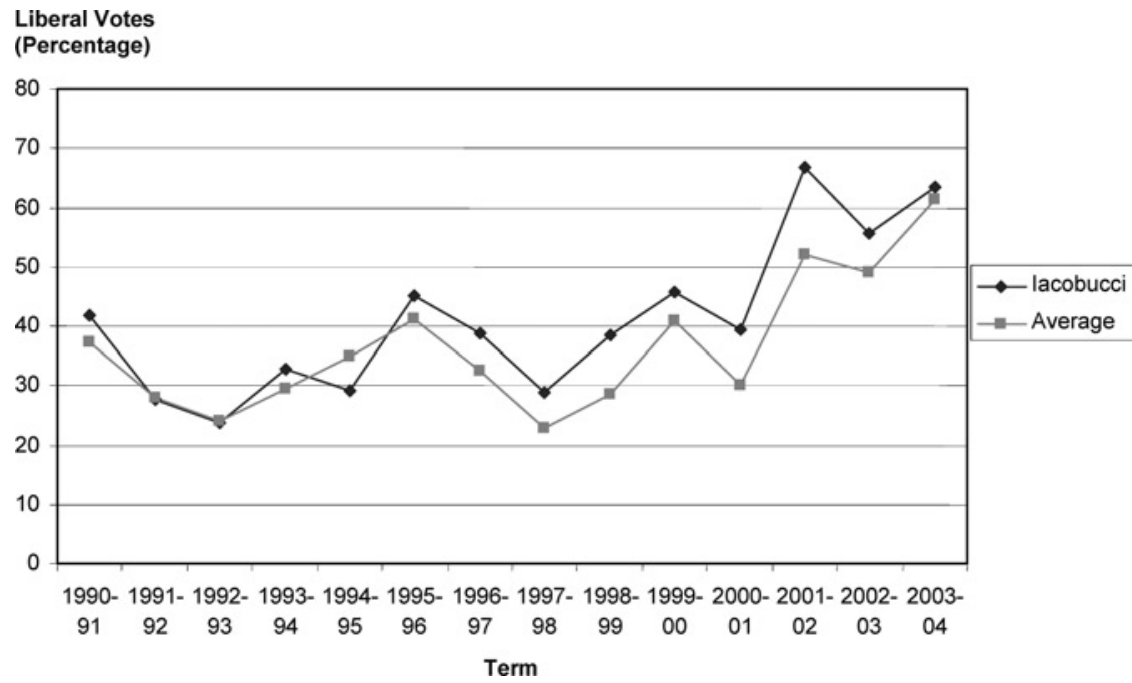


membership of the bench changes. A change in voting records may occur where the change in membership affects the dynamics of decision making on the Court. Part IV addresses some of the issues surrounding panel effects and Justice Iacobucci's role on the Court as a consensus builder.

\section{Coalitions and the Median Voter}

A general sense of Justice Iacobucci's contribution to the Court can be derived from the dataset based on various measures of his workload, his penchant for writing, and his tendency either to be in the majority or to dissent in divided decisions. During Justice Iacobucci's time on the Supreme Court, the Court heard, on average, approximately 95 appeals per term, with a low of 68 in 1998-9 and a high of 117 in 1991-2. Justice Iacobucci's initial time on the bench was particularly busy, with the Court hearing on average 108 appeals per term between the 1990-1 and 1997-8 terms and just 77 appeals on average from September 1998 to June 2004. Of the 95 appeals heard in an average year, Justice Iacobucci was assigned to 78 and authored, on average, about 13 judgments per year. The mix of the judgments he wrote changed dramatically from year to year, with a decline in unanimous judgments from 62.5 per cent in $1990-1$ to 15.4 per cent in 1995-6 and then a significant and relatively steady increase up to 73.3 per cent in 2001-2. This is curious, since there was no similarly large swing in the rate of Court unanimity in these years (54.3 per cent in 1990-1, 56.5 per cent in 1995-6, and 67.6 per cent in 2001-2). During his tenure on the Court, Justice Iacobucci participated in decisions at a rate equal to the Court average, sitting on 82 per cent of appeals. He was one of the least frequent dissenters on the Court over the period, ${ }^{40}$ dissenting in just 4.96 per cent $(1$ in 20.2 ) of the appeals he sat on, compared with the Court average of 7.93 per cent (1 in 12.6). By way of contrast, Justice L'Heureux-Dubé dissented in 14.40 per cent ( 1 in 6.9 ) and Justice Deschamps dissented in 12.03 per cent (1 in 8.3) of appeals.

An interesting result of an analysis of the cases in which Justice Iacobucci authored a judgment is that he took a strong leadership position in tax appeals. When Justice Iacobucci was assigned to panels hearing tax appeals, he wrote unanimous and majority judgments more frequently than any other member of the Court - a high of 51.9 per cent of the time when the Court was unanimous and 50 per cent of the time when he joined the majority. Justice Iacobucci also

40 Only Stevenson (3.96 per cent) and Cory (4.56 per cent) dissented less frequently than Iacobucci. 
demonstrated leadership (defined, for this purpose, as authoring more than his share of unanimous judgments) in administrative, corporate, immigration, and public law appeals. Justice Iacobucci wrote less frequently for unanimous panels in constitutional and Charter appeals but wrote rather frequently for the majority in such cases (27.3 per cent and 23.5 per cent respectively).

What we are most interested in for the purposes of this section is with whom Justice Iacobucci agreed (or disagreed) in the appeals in which he participated. Over his tenure, about 60.6 per cent of the cases heard by the Court were decided unanimously, which shows a remarkably high rate of agreement among all the justices on a panel. The remaining 39.4 per cent of cases had at least one justice who did not join the majority opinion and instead opted to write a dissent or a concurring opinion. In these non-unanimous appeals, Justice Iacobucci joined the majority opinion 78.7 per cent of the time, concurred 8.1 per cent of the time, and dissented in 13.3 per cent of the appeals. The only other justice who had a comparably high rate of joining the majority in nonunanimous appeals was Justice Cory, who joined the majority opinion 79.5 per cent of the time, concurred 9.1 per cent, and dissented in 11.4 per cent of the non-unanimous appeals. At the opposite end of the spectrum was Justice L'Heureux-Dubé, who, at just 40.6 per cent of the time, joined the majority in divided appeals about half as frequently as Justices Iacobucci and Cory did. Justice L'Heureux-Dubé concurred in 26.8 per cent and dissented in 32.6 per cent of the non-unanimous appeals she participated in.

Table 7 examines which justices Justice Iacobucci tended to agree with in the sense of joining the same judgment (majority, concurring, or dissent). These figures were derived by dividing the number of cases the relevant pair of justices agreed on (majority, concurring, or dissent) by the total number of cases they sat on together. The justices are arrayed such that the percentage of agreement declines the further the justice is from Justice Iacobucci on the table. There were six justices with whom Justice Iacobucci agreed over 85 per cent of the time: Justices Arbour, Cory, Binnie, Major, Fish, and Sopinka. Although these results are not reported in the table, if the agreement level is examined across the five areas of law we used to examine the justice's liberal voting record, Justice Iacobucci's 85 per cent agreement rate persists across the five types of law (criminal, Charter, Aboriginal, labour, and tax) with Justices Arbour and Cory. It remains over 85 per cent with Justice Major within four areas (criminal, Aboriginal, labour, and tax), with Justice Binnie within three areas (criminal, labour, and tax), and with Justice Sopinka within three areas (criminal, Aboriginal, and tax). The close association that Justice Iacobucci had with Justice Cory is consistent with the common observation that Justices Cory and Iacobucci 
THE REASONABLE JUSTICE 223

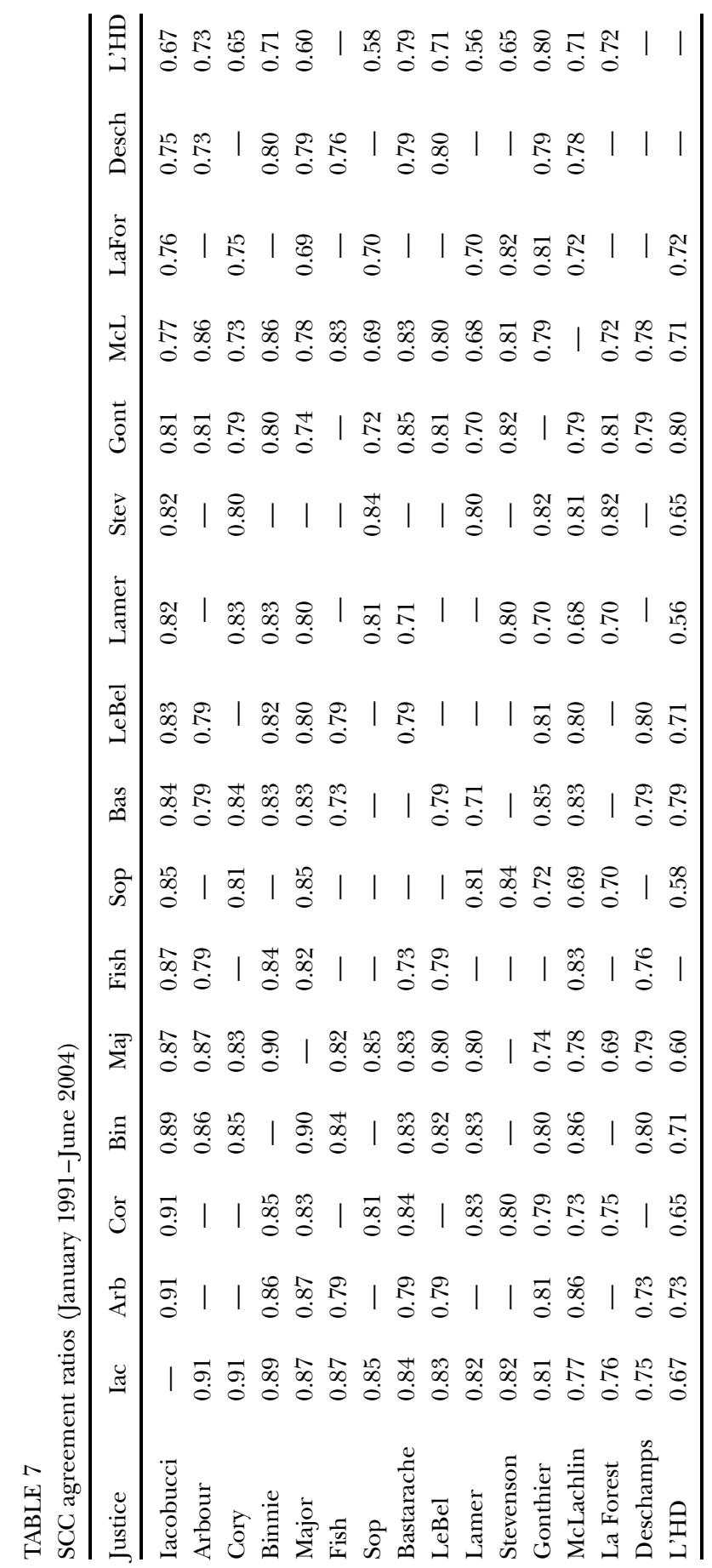


frequently decided appeals in the same way, often providing jointly authored reasons. ${ }^{41}$

Two particularly interesting points emerge from combining the information in Table 7 and in Tables 5 and 6. First, the two justices Justice Iacobucci agreed with most were Justice Cory, who left the bench in 1999, and Justice Arbour, who replaced Cory the same year. The rates of agreement were the same, although the liberal voting records of Justices Cory and Arbour were very different. Justice Arbour, in fact, had an approximately 16-per-cent higher liberal voting record than Justice Cory (and an ideal point that was nearly half a point higher). Second, each justice who joined the Court in this period had a higher percentage liberal voting record than the justice who was replaced (Table 5) and demonstrated a higher rate of agreement with Justice Iacobucci (Table 7). This pattern of agreement provides some insight into the change in Justice Iacobucci's voting record over time. The change towards more liberal voting may, in part, have been due to the change in the membership in the Court. While it is difficult to sort out cause and effect from this data (for example, there was also a change in the mix of cases within categories over the period), Justice Iacobucci may have voted more liberally over this period because he valued consensus and by voting more liberally was able to secure agreement more readily with his newer, more liberal-oriented colleagues. The other possibility, of course, is that Justice Iacobucci's shift to the left (documented above in Figure 4) exerted particular influence on the newer members of the Court.

The indirect, Quinn-Martin method of assessing the policy preferences of the justices reveals Justice Iacobucci to be slightly to the left of the centre of the Court and very nearly at its centre. Of the fifteen justices he served with, Justice Iacobucci ranks as the seventh most liberal overall, the ninth most liberal in Charter appeals, and sixth most liberal in criminal appeals (though essentially tied with Justices Binnie and Cory, who place seventh and eighth, respectively). The Quinn-Martin analysis also shows the SCC to be a narrowly distributed group, at least as compared with the USSC. The unpredictability of the way the justices will split on any given appeal (with just a few exceptions) suggests that the SCC has been a collegial Court, with each justice amenable to reconsidering on the basis of the arguments of colleagues. This, in turn, suggests that some gravitational force is bringing the justices toward the centre of the distribution. It is, of course, unclear what this gravitational force

41 See Kirk Makin, 'Emotional,' supra note 1, citing Jamie Cameron as stating: 'The number of joint opinions they have produced is striking. It raises the issue of how his jurisprudence will evolve, now that he has lost his greatest friend and, maybe, his mentor.' 
is, but at least two non-mutually-exclusive possibilities are clear. The first of these possibilities is that the justices take the law - that is, precedent and legislation, seriously - which thus operates as a real constraint on the perceived legitimate bounds of disagreement. The second possibility is that, to the extent that the law gives rise to a number of reasonable and legitimate alternatives, the Court has been under the influence of one or more justices who have effectively emphasized the value of agreement and consensus in a manner sufficiently persuasive to draw towards the centre those of opposing leanings.

\section{Conclusion}

At the time of Justice Iacobucci's appointment, Jacob Ziegel referred to Justice Iacobucci as 'by nature a middle-of-the-road [person]. He is a man of balanced views. He's not extreme in either direction. I would say he embodies very much the [views of] the average intelligent and sensitive Canadian.' ${ }^{42}$ This view accords with an analysis of newspaper editorials at the time of his appointment, which identified Justice Iacobucci as a centrist. ${ }^{43}$ Yet, by the end of his time on the Court, he was viewed as being a liberal. Both our direct and indirect analyses show that, overall, Justice Iacobucci was at the centre of the Court and shading a little to the left of centre in relation to others on the Court. Part III also shows that these straight-average liberal voting percentages over the period hide a significant shift in voting by both Justice Iacobucci and the Court. Both had a fairly conservative voting record at the beginning of the 1990s, but ten years later, they had shifted to the left.

One of the interesting results from this analysis is that Mulroney may have guessed correctly if he believed that Justice Iacobucci would vote with what was at the time a relatively conservative court. Moreover, there appears to be a connection between the change in the voting of the Court and the replacement of justices appointed by Conservative

42 Cristin Schmitz, 'Scholars, Jurists, Lawyers Hail Iacobucci Appointment' Lawyers Weekly (25 January 1991) 24, citing Jacob Ziegel.

43 A study of the language in newspaper editorials at the time of appointment of Supreme Court justices ranked Iacobucci as 0 on a scale of +2 (very liberal) to -2 (very conservative) - that is, he was regarded as being right in the middle. The study was based on the wording used in each editorial and scored the language in the Globe and Mail at - 1, in the Ottawa Citizen at 0, and in the six other regional newspapers at 0.250 , with a cumulative score of 0 ; see Ostberg et al., 'Nature and Extent,' supra note 27. This method of ranking justices derives from US attempts to measure judicial attitudes independently of their voting patterns. See Jeffrey Segal \& Albert Cover, 'Ideological Values and Votes of United States Supreme Court Justices' (1989) 83 Am.Pol.Sc.Rev. 557. 
prime ministers (largely Mulroney) with those appointed by Jean Chrétien, a Liberal. However, Justice Iacobucci's voting record illustrates that what appointing prime ministers cannot control are the changes that justices undergo as they grow in experience on the Court, as the membership of the Court changes, as the mix of appeals changes, or as Canadian society changes and develops. More work is needed both on the strength of the connection between the party of the prime minister appointing justices and the voting records of those justices and on the changes in justices' voting over their judicial careers.

Reaching firm conclusions on consensus building is difficult because it is impossible to determine from observations of the disposition of appeals what, in fact, has caused justices to vote in particular ways. The best that can be done is to search our analyses for evidence that would disconfirm the view that Justice Iacobucci was a consensus builder in his time on the Court. We find nothing that suggests that Justice Iacobucci was not a consensus builder on the Court and find evidence that is consistent with an increasing ability to reach agreement with colleagues during his tenure. Among the key evidence is Justice Iacobucci's low rate of dissent (about 5 per cent versus the Court average of 8 per cent); his high rate of agreement with his colleagues (particularly with Justices Cory and Arbour, though also with Justices Binnie, Major, Fish, and Sopinka); the narrow distribution of justices' ideal points around the centre of the Court and Justice Iacobucci's position near the centre of this distribution; and the high rate at which Justice Iacobucci wrote for unanimous panels, especially in the second half of his tenure. Aside from consensus building, however, there are other potential explanations, such as the possibility that the justices of the SCC take the pre-existing legal constraints more seriously than do other courts (such as the USSC) or that the justices simply happen to be relatively centrist. While we cannot dismiss the possibility that these other explanations account for the consensus observed in our analyses, the fact that both the direct and indirect analyses provide results consistent with the view bolsters it considerably. 